Virginia Commonwealth University

vCU Scholars Compass

1998

\title{
Interferon Alfa-2b Alone or in Combination with Ribavirin for the Treatment of Relapse of Chronic Hepatitis C
}

\author{
Gary L. Davis , M.D. \\ University of Florida \\ Rafael Esteban-Mur, M.D. \\ Hospital Vall d'Hebron \\ Vinod Rustgi, M.D. \\ Inova Institute of Research and Education \\ See next page for additional authors
}

Follow this and additional works at: http://scholarscompass.vcu.edu/intmed_pubs

Part of the Medicine and Health Sciences Commons

From The New England Journal of Medicine, Davis, G.L., Esteban-Mur, R., Rustgi, V., et al. Interferon Alfa-2b Alone or in Combination with Ribavirin for the Treatment of Relapse of Chronic Hepatitis C, Vol. 339, Page 1493, Copyright (C) 1998 Massachusetts Medical Society. Reprinted with permission.

\section{Downloaded from}

http://scholarscompass.vcu.edu/intmed_pubs/56

\footnotetext{
This Article is brought to you for free and open access by the Dept. of Internal Medicine at VCU Scholars Compass. It has been accepted for inclusion in Internal Medicine Publications by an authorized administrator of VCU Scholars Compass. For more information, please contact libcompass@vcu.edu.
} 
Authors

Gary L. Davis , M.D.; Rafael Esteban-Mur , M.D.; Vinod Rustgi , M.D.; John Hoefs , M.D.; Stuart C. Gordon , M.D.; Christian Trepo , M.D.; Mitchell L. Shiffman , M.D.; Stefan Zeuzem , M.D.; Antonio Craxi , M.D.; MeiHsui Ling, Ph.D.; and Janice Albrecht, Ph.D. 


\title{
INTERFERON ALFA-2b ALONE OR IN COMBINATION WITH RIBAVIRIN FOR THE TREATMENT OF RELAPSE OF CHRONIC HEPATITIS C
}

\author{
Gary L. Davis, M.D., Rafael Esteban-Mur, M.D., Vinod Rustgl, M.D., John Hoefs, M.D., Stuart C. Gordon, M.D., \\ Christian Trepo, M.D., Mitchell L. Shiffman, M.D., Stefan Zeuzem, M.D., Antonio Craxi, M.D., \\ Mei-Hsiu Ling, Ph.D., and Janice Albrecht, Ph.D., for the International Hepatitis Interventional Therapy Group*
}

\begin{abstract}
Background Interferon alfa is the only effective treatment for patients with chronic hepatitis C. Forty percent of patients have an initial response to this therapy, but most subsequently relapse. We compared the effect of interferon alone with that of interferon plus oral ribavirin for relapses of chronic hepatitis C.

Methods We studied 345 patients with chronic hepatitis $C$ who relapsed after interferon treatment. A total of 173 patients were randomly assigned to receive standard-dose recombinant interferon alfa-2b concurrently with ribavirin (1000 to $1200 \mathrm{mg}$ orally per day, depending on body weight) for six months, and 172 patients were assigned to receive interferon and placebo.
\end{abstract}

Results At the completion of treatment, serum levels of hepatitis $\mathrm{C}$ virus (HCV) RNA were undetectable in 141 of the 173 patients who were treated with interferon and ribavirin and in 80 of the 172 patients who were treated with interferon alone (82 percent vs. 47 percent, $\mathrm{P}<0.001)$. Serum HCV RNA levels remained undetectable 24 weeks after the end of treatment in 84 patients (49 percent) in the combinationtherapy group, but in only 8 patients ( 5 percent) in the interferon group $(\mathrm{P}<0.001)$. Sustained normalization of serum alanine aminotransferase concentrations and histologic improvement were highly correlated with virologic response. Base-line serum HCV RNA levels of $2 \times 10^{6}$ copies per milliliter or less were associated with higher rates of response in both treatment groups. Viral genotypes other than type 1 were associated with sustained responses only in the combination-therapy group. Combined therapy caused a predictable fall in hemoglobin concentrations but otherwise had a safety profile similar to that of interferon alone.

Conclusions In patients with chronic hepatitis C who relapse after treatment with interferon, therapy with interferon and oral ribavirin results in higher rates of sustained virologic, biochemical, and histologic response than treatment with interferon alone. (N Engl J Med 1998;339:1493-9.)

(C)1998, Massachusetts Medical Society.

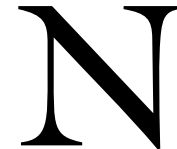

EARLY 4 million people in the United States and 100 million worldwide are infected with the hepatitis $\mathrm{C}$ virus (HCV). ${ }^{1}$ Of these, approximately 70 percent have chronic hepatitis and 15 to 20 percent will eventually have cirrhosis. ${ }^{2-4}$ Chronic hepatitis $\mathrm{C}$ is the most common cause of chronic liver disease and the leading indication for liver transplantation in the United States. ${ }^{1,5}$

Interferon alfa is the only effective treatment for

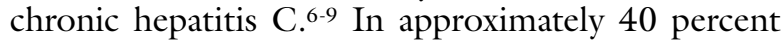
of patients, serum alanine aminotransferase concentrations fall to normal and HCV RNA disappears from serum during short courses of treatment, but most patients relapse soon after stopping therapy. ${ }^{6-9}$ Although longer courses of treatment (12 to 24 months) increase the duration of the initial response, many patients still relapse. ${ }^{10-13}$

Ribavirin is a synthetic nucleoside analogue with in vitro activity against several viruses..$^{14}$ Treatment with ribavirin alone reduces serum alanine aminotransferase concentrations, but not serum HCV RNA levels, in patients with chronic hepatitis C.15-17 Pilot studies suggested that the combination of interferon and ribavirin reduced relapse, as compared with interferon alone, thereby increasing the likelihood of a sustained response. ${ }^{18-21}$ Furthermore, among eight patients who relapsed after an initial response to interferon, six had a sustained response to combination treatment. ${ }^{18}$ By comparison, treatment of patients who relapse with the same dose of interferon that was used initially rarely results in a sustained response. 22,23

The aim of this study was to compare the safety and efficacy of recombinant interferon alfa- $2 b$ alone and in combination with oral ribavirin for the treatment of patients with chronic hepatitis $\mathrm{C}$ who relapsed after a response to interferon therapy.

From the University of Florida College of Medicine, Gainesville (G.L.D.); Hospital Vall d'Hebron, Barcelona, Spain (R.E.-M.); Inova Institute of Research and Education, Falls Church, Va. (V.R.); University of California at Irvine, Orange (J.H.); William Beaumont Hospital, Royal Oak, Mich. (S.C.G.); Hôpital Hotel Dieu, Lyons, France (C.T.); Medical College of Virginia, Richmond (M.L.S.); Klinikum der J.W. Goethe Universität, Frankfurt, Germany (S.Z.); Policlinico P. Giaccone, Palermo, Italy (A.C.); and Schering-Plough Research Institute, Kenilworth, N.J. (M.-H.L., J.A.). Address reprint requests to Dr. Davis at the Section of Hepatobiliary Diseases, Box 100214, University of Florida College of Medicine, Gainesville, FL 32610-0214.

${ }^{*}$ The other members of the International Hepatitis Interventional Therapy Group are listed in the Appendix. 


\section{METHODS}

\section{Patients}

Adult patients with chronic hepatitis $\mathrm{C}$ who had previously received one or two courses of recombinant or lymphoblastoid interferon alfa (interferon alfa-2b [Intron A], Schering-Plough, Kenilworth, N.J.; interferon alfa-2a [Roferon-A], Hoffmann-La Roche, Nutley, N.J.; or interferon alfa-nl [Wellferon], Glaxo Wellcome, Research Triangle Park, N.C.) at a dose of 3 million to 6 million units three times per week for at least 20 weeks but not more than 18 months without a reduction in the dose or an interruption in treatment were eligible for the study. The patients had to have had a response to the most recent course of interferon - defined as a normal serum alanine aminotransferase concentration at the end of therapy - followed by a relapse, with an elevation in serum alanine aminotransferase concentrations, within one year after treatment was stopped. All patients also had to have undergone a liver biopsy showing chronic hepatitis after they had relapsed and within six months before enrollment. All women in the study were required to use effective birth control. The following were reasons for exclusion: decompensated cirrhosis, ${ }^{6}$ a hemoglobin concentration of less than $12 \mathrm{~g}$ per deciliter in women and less than $13 \mathrm{~g}$ per deciliter in men, a white-cell count of less than 3000 per cubic millimeter, a neutrophil count of less than 1500 per cubic millimeter, a platelet count of less than 100,000 per cubic millimeter, human immunodeficiency virus infection, prior organ transplantation, severe psychiatric conditions, a seizure disorder, cardiovascular disease, renal insufficiency, hemoglobinopathy, hemophilia, poorly controlled diabetes mellitus, and immunologically mediated diseases.

\section{Study Design and Treatment Regimens}

The study was a double-blind, placebo-controlled trial conducted in the United States and internationally. The patients were randomly assigned to treatment by a centralized computer algorithm that stratified enrollment according to the presence of cirrhosis, high serum HCV RNA levels, and HCV genotype 1 - all of which reduce the response to interferon. ${ }^{24,25}$ The treatments consisted of 24 weeks of subcutaneous interferon alfa- $2 b$ at a dose of 3 million units three times per week plus either oral ribavirin (Rebetron, Schering-Plough), administered twice daily at a total daily dose of $1000 \mathrm{mg}$ (for patients who weighed $75 \mathrm{~kg}$ or less) or $1200 \mathrm{mg}$ (for those who weighed more than $75 \mathrm{~kg}$ ), or a matched placebo.

A total of 495 patients were screened, of whom 349 met the entry criteria and were assigned to a treatment group. Four patients withdrew before receiving treatment. Therefore, $173 \mathrm{pa}-$ tients received interferon and ribavirin (77 in the United States and 96 at international sites), and 172 patients received interferon and placebo (76 in the United States and 96 at international sites). The patients were evaluated after $1,2,4,6$, and 8 weeks of treatment and then monthly thereafter and $4,8,12$, and 24 weeks after treatment was discontinued.

All biochemical and hematologic tests were performed in central laboratories. Serum was collected and stored under conditions known to optimize the detection of HCV RNA. ${ }^{26}$ Serum HCV RNA was measured before treatment, at the end of treatment, and at the last follow-up visit by a quantitative reverse-transcription-polymerase-chain-reaction assay with a lower limit of detection of 100 copies per milliliter (National Genetics Institute, Culver City, Calif.). A liver biopsy was performed at the end of the follow-up period.

The study was conducted between April 1996 and July 1997. The protocol was approved by the institutional review committee at each site, and all patients provided written informed consent.

\section{End Points}

The primary end points were the disappearance of HCV RNA from serum and histologic improvement at the end of the 24week follow-up period. In patients who have undetectable serum
HCV RNA levels for 24 weeks after treatment, the concentrations remain undetectable indefinitely. ${ }^{27}$ For consistency with other reports and current clinical practice, we also reported conventional end points as defined by the National Institutes of Health Consensus Development Conference on Hepatitis C. ${ }^{28}$ These include a response at the end of treatment (defined as normal serum alanine aminotransferase concentrations and undetectable serum HCV RNA levels at the end of therapy) and a sustained response (defined as a response that persists for at least six months after treatment).

Liver-biopsy specimens obtained before treatment and at the end of the follow-up period were interpreted by a single pathologist who was unaware of the patients' treatment assignment or the timing of the biopsy. The degree of hepatic inflammation and fibrosis was scored with the Knodell Histologic Activity Index ${ }^{29}$ and the Metavir system, ${ }^{30}$ respectively. The inflammation score was obtained by combining the scores for the first three components of the Knodell index (portal, periportal, and lobular inflammation). The scores can range from 0 to 18 , and higher scores indicate more severe abnormalities. Histologic improvement was defined as a decrease in the inflammation score of at least two points. Fibrosis was graded according to the Metavir system, in which a score of 0 indicates the absence of fibrosis and a score of 4 indicates cirrhosis.

\section{Statistical Analysis}

The analysis was based on the 345 patients who received treatment. The demographic information, viral characteristics, and treatment responses for the U.S. patients and the patients at international sites were nearly identical, and the data were therefore combined. The base-line characteristics of the treatment groups were compared with use of the chi-square test or the Wilcoxon rank-sum test. ${ }^{31}$ Treatment responses were compared with use of the Cochran-Mantel-Haenszel test or analysis of variance (for liver-biopsy specimens). ${ }^{31}$ The relatedness of various pretreatment characteristics to the response was examined with use of stepwise logistic-regression analysis. ${ }^{31}$ All statistical tests were two-tailed.

\section{RESULTS}

\section{Characteristics of the Patients}

The two treatment groups were well matched (Table 1). Most patients had previously received a single course of interferon alfa- $2 b$ that lasted less than 12 months. The pretreatment serum HCV RNA levels, the percentage of patients with $\mathrm{HCV}$ genotype 1, and the numbers of patients with fibrosis and cirrhosis were similar in the two groups. The proportions with $\mathrm{HCV}$ genotype 1 or cirrhosis were lower than in most trials of previously untreated patients with chronic hepatitis $\mathrm{C}$, because patients with these characteristics are less likely to have an initial response to interferon therapy and therefore would not have had the opportunity to relapse and qualify for this study.

\section{Serum HCV RNA}

Serum HCV RNA levels became undetectable by the end of treatment in 141 of the 173 patients $(82$ percent) who were treated with interferon and ribavirin and in 80 of the 172 patients ( 47 percent) who were treated with interferon alone $(\mathrm{P}<0.001)$. Among the patients in whom serum levels of HCV RNA were undetectable at the end of treatment, the levels became undetectable during the first four weeks of treatment in 124 of the 141 patients ( 88 percent) in 
Table 1. Base-Line Characteristics of the Patients.*

\begin{tabular}{|c|c|c|}
\hline Characteristic & $\begin{array}{l}\text { INTERFERON } \\
(\mathrm{N}=172)\end{array}$ & $\begin{array}{l}\text { INTERFERON } \\
\text { AND RIBAVIRIN } \\
\text { (N=173) }\end{array}$ \\
\hline Male sex — no. (\%) & $112(65)$ & $112(65)$ \\
\hline $\begin{array}{l}\text { Age }- \text { yr } \\
\text { Mean } \\
\text { Range }\end{array}$ & $\begin{array}{l}42 \\
26-76\end{array}$ & $\begin{array}{l}44 \\
23-69\end{array}$ \\
\hline White race - no. $(\%)$ & $158(92)$ & $165(95)$ \\
\hline Weight $-\mathrm{kg}$ & $74.7 \pm 13.3$ & $75.6 \pm 15.1$ \\
\hline $\begin{array}{l}\text { Estimated duration of infection }- \text { yr } \dagger \\
\text { Mean } \\
\text { Range }\end{array}$ & $\begin{array}{c}16 \pm 8 \\
1.5-38\end{array}$ & $\begin{array}{l}15 \pm 8 \\
1.4-38\end{array}$ \\
\hline $\begin{array}{l}\text { Source of infection }- \text { no. }(\%) \\
\text { Transfusion } \\
\text { Injection-drug use } \\
\text { Unknown }\end{array}$ & $\begin{array}{l}52(30) \\
68(40) \\
52(30)\end{array}$ & $\begin{array}{l}42(24) \\
70(40) \\
61(35)\end{array}$ \\
\hline $\begin{array}{l}\text { Genotype - no. }(\%) \\
1 \\
2 \\
3 \\
\text { Mixed or other }\end{array}$ & $\begin{array}{l}94(55) \\
34(20) \\
39(23) \\
5(3)\end{array}$ & $\begin{array}{l}98(57) \\
25(14) \\
46(27) \\
4(2)\end{array}$ \\
\hline $\begin{array}{l}\text { Serum HCV RNA } \\
\text { No. of copies } / \mathrm{ml} \\
>2 \times 10^{6} \text { copies } / \mathrm{ml}-\text { no. }(\%)\end{array}$ & $\begin{array}{l}5.2 \times 10^{6} \\
131(76)\end{array}$ & $\begin{array}{l}4.8 \times 10^{6} \\
128(74)\end{array}$ \\
\hline Bridging fibrosis - no. $(\%)$ & $29(17)$ & $23(13)$ \\
\hline Cirrhosis — no. (\%) & $6(3)$ & $3(2)$ \\
\hline Fibrosis score $\ddagger$ & $1.3 \pm 0.7$ & $1.2 \pm 0.6$ \\
\hline Knodell score $\$$ & $6.8 \pm 2.6$ & $6.7 \pm 2.6$ \\
\hline $\begin{array}{l}\text { Serum alanine aminotransferase - } \\
\text { no. of times upper limit of normal } \\
\text { Mean } \\
\text { Range }\end{array}$ & $\begin{array}{l}3.0 \pm 1.9 \\
1.0-11.2\end{array}$ & $\begin{array}{l}3.2 \pm 2.1 \\
1.0-13.9\end{array}$ \\
\hline $\begin{array}{l}\text { Previous therapy } \\
\text { Interferon alfa- } 2 \mathrm{~b}-\text { no. }(\%) \\
\text { Single course }- \text { no. }(\%) \\
<12 \text { mo in duration - no. }(\%) \\
\text { Median duration - days }\end{array}$ & $\begin{array}{l}118(69) \\
154(90) \\
149(87) \\
190\end{array}$ & $\begin{array}{l}131(76) \\
161(93) \\
153(88) \\
185\end{array}$ \\
\hline $\begin{array}{l}\text { Time from end of last treatment to } \\
\text { enrollment }- \text { no. (\%) } \\
\leqslant 12 \mathrm{mo} \\
13-24 \mathrm{mo} \\
>24 \mathrm{mo}\end{array}$ & $\begin{array}{l}63(37) \\
69(40) \\
40(23)\end{array}$ & $\begin{array}{l}75(43) \\
48(28) \\
50(29)\end{array}$ \\
\hline
\end{tabular}

*Plus-minus values are means \pm SD. There were no significant differences between the two groups. Because of rounding, percentages may not total 100 .

$\dagger$ The duration of infection was estimated from the date of transfusion or first exposure.

$\ddagger$ Scores could range from 0 to 4 , with a score of 4 indicating cirrhosis.

$\$$ Scores could range from 0 to 18 , with higher scores indicating more severe abnormalities.

the combination-therapy group and in 44 of the 80 patients ( 55 percent) in the interferon group.

Serum HCV RNA levels remained undetectable throughout the follow-up period (defined as a sustained virologic response) in 84 patients ( 49 percent) in the combination-therapy group, but in only $8 \mathrm{pa}-$ tients $(5$ percent $)$ in the interferon group $(\mathrm{P}<0.001)$. The response was more likely to be sustained in patients in whom serum HCV RNA levels became undetectable during the first four weeks of treatment than in those with a later response $(87$ percent vs. 59 percent in the combination-therapy group, 42 percent vs. 10 percent in the interferon group). In all patients who had sustained responses, serum HCV RNA levels became undetectable before 12 weeks of treatment.

\section{Serum Alanine Aminotransferase}

Serum alanine aminotransferase concentrations were normal by the end of treatment in 154 of the 173 patients (89 percent) in the combination-therapy group and in 98 of the 172 patients ( 57 percent) in the interferon group $(\mathrm{P}<0.001)$. Among the patients with such a response, those treated with combination therapy were more likely to have undetectable serum HCV RNA levels than those treated with interferon alone ( 85 percent vs. 70 percent, $\mathrm{P}=$ $0.007)$. The serum alanine aminotransferase concentrations remained normal throughout follow-up in 81 patients (47 percent) in the combination-therapy group, as compared with only 8 patients ( 5 percent) in the interferon group $(\mathrm{P}<0.001)$.

Discrepancies between the serum HCV RNA responses and the alanine aminotransferase responses to interferon therapy have been reported. 32 In this study, serum HCV RNA levels remained detectable after treatment despite persistently normal serum alanine aminotransferase concentrations in 10 of 89 patients (11 percent) in the combination-therapy group and in 18 of 164 patients (11 percent) in the interferon group. In contrast, all but three patients in whom serum HCV RNA levels became undetectable had normal serum alanine aminotransferase concentrations.

\section{Traditional Treatment End Points}

When we assessed conventional end points defined according to the National Institutes of Health Consensus Development Conference, ${ }^{28}$ we found that 133 patients (77 percent) in the combination-therapy group had a response at the end of treatment, as compared with 69 patients ( 40 percent) in the interferon group. The rates of sustained response were 47 percent ( 81 patients) and 5 percent ( 8 patients), respectively.

\section{Histologic Analysis}

Pretreatment and post-treatment liver-biopsy specimens were available from 277 patients. Forty-eight patients refused to undergo or did not return for a second biopsy, 14 had inadequate biopsy specimens, the tissue blocks were lost in the case of 3 patients, a post-treatment biopsy was considered unsafe in the case of 2 patients, and 1 patient died.

Histologic improvement occurred in both treatment groups, but it was more common in the group treated with interferon and ribavirin (87 of $139 \mathrm{pa}^{-}$ tients, 63 percent) than in the group treated with in- 
Table 2. Rates of Sustained Response to Treatment According to the HCV Genotype, Base-Line Serum HCV RNA Level, and the Presence of Fibrosis or Cirrhosis on Liver BIOpSy at Base LiNe.

\begin{tabular}{|c|c|c|}
\hline \multirow[t]{2}{*}{ ChARACteristic } & INTERFERON & $\begin{array}{l}\text { INTERFERON } \\
\text { AND RIBAVIRIN* }\end{array}$ \\
\hline & \multicolumn{2}{|c|}{ no./total no. of patients (\%) } \\
\hline \multicolumn{3}{|l|}{ Genotype } \\
\hline 1 & $3 / 94 \quad(3)$ & $29 / 98 \quad(30) t$ \\
\hline Other & $5 / 78 \quad(6)$ & $55 / 75 \quad(73)$ \\
\hline \multicolumn{3}{|l|}{ Base-line HCV RNA level } \\
\hline$>2 \times 10^{6}$ copies $/ \mathrm{ml}$ & $2 / 131(2) \ddagger$ & $54 / 128(42)$ \\
\hline$\leqslant 2 \times 10^{6}$ copies $/ \mathrm{ml}$ & $6 / 41 \quad(15)$ & $30 / 45 \quad(67)$ \\
\hline \multicolumn{3}{|c|}{ Degree of fibrosis at base line } \\
\hline Fibrosis or cirrhosis [ & $1 / 35 \quad(3)$ & $12 / 26 \quad(46)$ \\
\hline Minimal or no fibrosis & $6 / 134(4)$ & $70 / 142(49)$ \\
\hline
\end{tabular}

${ }^{*} \mathrm{P}<0.001$ for the comparison with interferon alone for each characteristic tested.

$\dagger \mathrm{P}<0.001$ for the comparison with the other genotypes.

$\ddagger \mathrm{P}=0.003$ for the comparison with a serum HCV RNA level of $\leqslant 2 \times 10^{6}$ copies per milliliter.

$\$ \mathrm{P}=0.006$ for the comparison with a serum HCV RNA level of $\leqslant 2 \times 10^{6}$ copies per milliliter.

ISeptal fibrosis was defined by a Metavir score of 2 or 3, and cirrhosis by a score of 4 . Liver-biopsy specimens were insufficient for analysis in the case of three patients in the interferon group and five patients in the combination-therapy group.

Table 3. Relation of Viral Genotype and Base-Line Serum HCV RNA LeVel to the RESPONSE TO TREATMENT.

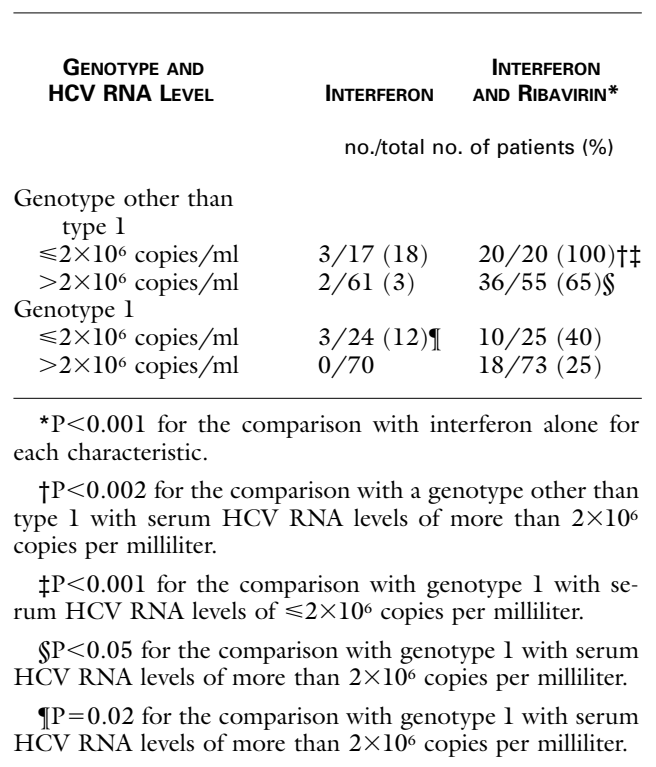

terferon alone (57 of 138 patients, 41 percent; $\mathrm{P}<$ $0.001)$. The mean decreases in the inflammatory scores were 2.6 and 0.7 , respectively $(\mathrm{P}<0.001)$. Histologic improvement was strongly associated with a sustained loss of serum HCV RNA regardless of the treatment $(\mathrm{P}<0.001)$. Among patients in whom serum HCV RNA levels remained detectable, the mean decline in the levels was similar in those with histologic improvement and those without histologic improvement.

\section{Correlation of Base-Line Characteristics with Response}

The HCV genotype, pretreatment serum HCV RNA levels, and the presence of fibrosis or cirrhosis at base line influence the initial response to treatment with interferon alone. ${ }^{25,33,34}$ Patients who were treated with combination therapy were more likely to have a sustained response regardless of the genotype, serum HCV RNA levels at base line, or histologic findings at base line (Table 2). However, in this group, a sustained viral response was more common in patients with serum HCV RNA levels of $2 \times 10^{6}$ copies per milliliter or less $(\mathrm{P}=0.006)$ or $\mathrm{HCV}$ genotypes other than type $1(\mathrm{P}<0.001)$. The combination of the viral genotype and the pretreatment serum HCV RNA level was significantly associated with a response to combination therapy (Table 3 ). In contrast, in patients who were treated with interferon alone, a sustained loss of serum HCV RNA was more common in those with pretreatment serum HCV RNA levels of $2 \times 10^{6}$ copies per milliliter or less $(\mathrm{P}=0.003)$, but it was not significantly influenced by the HCV genotype. The rate of response to either treatment was not influenced by the presence of fibrosis or cirrhosis at base line, age, sex, body weight, the presumed source of infection, or the type, dose, and duration of prior interferon treatment.

\section{Adverse Events}

Ribavirin accumulates in red cells and results in hemolysis. ${ }^{17}$ The mean $( \pm$ SE) hemoglobin concentration in the combination-therapy group fell from $14.4 \pm 1.2$ to $12.4 \pm 1.4 \mathrm{~g}$ per deciliter during the first month of treatment, remained stable thereafter, and returned to values that were close to base-line values within four weeks after treatment was stopped. The values fell below $11.0 \mathrm{~g}$ per deciliter in 43 patients ( 25 percent) and below $10.0 \mathrm{~g}$ per deciliter in $15 \mathrm{pa}-$ tients $(9$ percent $)$. The decline was accompanied by reticulocytosis (reticulocytes, $2.8 \pm 0.1$ percent). Fifteen patients ( 9 percent) had a serum total bilirubin concentration of more than $2 \mathrm{mg}$ per deciliter (34 $\mu$ mol per liter), and 42 patients ( 24 percent) had a high serum uric acid concentration. In the interferon group, the mean hemoglobin concentration decreased by $0.8 \pm 0.7 \mathrm{~g}$ per deciliter.

Both groups had similar decreases in the white- 
cell count (35 percent in the combination-therapy group and 23 percent in the interferon group) and neutrophil count (33 percent and 28 percent, respectively), with a nadir after four weeks of treatment and recovery within four weeks after treatment was stopped. The platelet counts also fell in both groups, but the decrease was smaller in the combination-therapy group than in the interferon group (7 percent vs. 15 percent).

Most patients had some symptoms during treatment (Table 4), but only nausea, dyspnea, and rash were significantly more common in the combination-therapy group than in the interferon group. The frequencies and types of other symptoms were similar to those reported in patients who were treated with interferon alone. ${ }^{35}$ Other than depression, no patient had any serious or potentially life-threatening complications, and there were no drug-related deaths. One woman in the interferon group who had a history of alcohol and injection-drug abuse committed suicide three months after treatment was stopped. She had not reported depression during interferon treatment. No other patient died, and none required liver transplantation.

The dose of interferon or ribavirin was reduced or treatment was discontinued for at least three days in 20 patients ( 12 percent) in the combination-therapy group, mostly because of anemia (12 patients), and in 5 patients ( 3 percent) in the interferon group. Treatment was discontinued in 10 patients $(6$ percent) in the combination-therapy group and in 5 ( 3 percent) in the interferon group. The reasons for discontinuation in the combination-therapy group included depression (five patients), neutropenia (two patients), hyperthyroidism with tachycardia (one patient), arthralgia (one patient), and cough (one patient); the reasons for discontinuation in the interferon group were suicidal ideation, nausea, dehydration, insomnia, and musculoskeletal pain (one patient each).

\section{DISCUSSION}

In approximately 40 percent of patients with chronic hepatitis $\mathrm{C}$, interferon therapy results in normalization of serum alanine aminotransferase concentrations, loss of detectable HCV RNA in serum, and histologic improvement, but the majority relapse shortly after treatment is stopped.6,8-10,36 Many but not all of these patients have a response to a second course of treatment, but sustained responses are uncommon. ${ }^{6,22,37-39}$ A second course of treatment with higher doses than the first course or for longer periods or both leads to sustained responses in 20 to 50 percent of patients, ${ }^{22,37-40}$ but these regimens are costly and poorly tolerated.

Our study confirms that after relapse, the results of treatment with the same dose of interferon that was used initially are disappointing. In contrast, however, treatment after relapse with a combination
Table 4. Rates of Symptoms during Treatment.*

\begin{tabular}{|c|c|c|}
\hline \multirow[t]{2}{*}{ SYMPTOM } & $\begin{array}{l}\text { INTERFERON } \\
(\mathbf{N}=172)\end{array}$ & $\begin{array}{l}\text { INTERFERON } \\
\text { AND RIBAVIRIN } \\
\text { (N=173) }\end{array}$ \\
\hline & \multicolumn{2}{|c|}{ percent } \\
\hline \multicolumn{3}{|l|}{ Influenza-like symptoms } \\
\hline Headache & 54 & 55 \\
\hline Fatigue or asthenia & 39 & 46 \\
\hline Myalgia & 39 & 44 \\
\hline Arthralgia & 23 & 21 \\
\hline Fever & 33 & 32 \\
\hline Rigors & 21 & 26 \\
\hline \multicolumn{3}{|c|}{ Gastrointestinal symptoms } \\
\hline Anorexia & 13 & 20 \\
\hline Nausea & 20 & $35 \dagger$ \\
\hline Diarrhea & 18 & 12 \\
\hline \multicolumn{3}{|l|}{ Psychiatric symptoms } \\
\hline Depression & 11 & 16 \\
\hline Insomnia & 23 & 20 \\
\hline \multicolumn{3}{|c|}{ Respiratory tract symptoms } \\
\hline Cough & 9 & 10 \\
\hline Dyspnea & 6 & $14 \ddagger$ \\
\hline Pharyngitis & 9 & 11 \\
\hline \multicolumn{3}{|l|}{ Dermatologic symptoms } \\
\hline Alopecia & 18 & 21 \\
\hline Rash & 5 & $13 \ddagger$ \\
\hline Pruritus & 6 & 13 \\
\hline
\end{tabular}

* Only symptoms that occurred in at least 10 percent of all patients were included.

$\dagger \mathrm{P}=0.002$ for the comparison with interferon alone.

$\ddagger \mathrm{P}=0.02$ for the comparison with interferon alone.

of interferon and ribavirin for just six months resulted in sustained loss of HCV RNA from serum in nearly half the patients, most of whom had histologic improvement.

The likelihood of a favorable response to treatment with either regimen after relapse was related to the pretreatment serum HCV RNA level. The results of previous studies of the importance of changes in HCV RNA levels with respect to the response to treatment with interferon after relapse are conflicting, $37,41,42$ possibly because of differences in the method of serum collection, ${ }^{26}$ the HCV RNA assay, ${ }^{43}$ or the viral response to the first course of treatment. Patients in whom serum alanine aminotransferase concentrations return to normal and serum HCV RNA levels become undetectable during the first course of interferon are more likely to have a response to treatment after relapse than those in whom serum alanine aminotransferase values return to normal but viremia persists. ${ }^{22}$ We do not know what proportion of our patients were seronegative for HCV RNA after their earlier course of interferon, because most had been treated in communities where these assays were not widely available.

The HCV genotype was strongly associated with the response to combination therapy. The genotype and the pretreatment serum HCV RNA level also 
appeared to be related, with rates of responses as high as 100 percent in patients with low serum HCV RNA levels at base line and a genotype other than type 1 . In contrast to previous reports, ${ }^{22}$ our data suggest that the HCV genotype has no influence on the response to treatment with interferon alone after relapse.

Both treatment regimens were safe and reasonably well tolerated. The only important risk associated with combination therapy was hemolytic anemia, as previously noted in trials of ribavirin alone. ${ }^{17}$ The fall in the hemoglobin concentration occurred during the first month of treatment and was sometimes substantial, thus emphasizing the need for careful monitoring of patients during treatment with ribavirin.

In summary, the combination of interferon and ribavirin is safe and effective for the treatment of patients with chronic hepatitis $\mathrm{C}$ who relapse after an initial response to therapy with interferon alone. Combination therapy offers a striking advantage over interferon monotherapy: it had a much higher rate of sustained response. Although treatment lasted only six months in our study, our results with combination therapy are as good as or better than those in patients who were treated with higher doses and longer courses of interferon. ${ }^{22,40}$ Furthermore, treatment with combination therapy after relapse frequently resulted in histologic improvement. The reduction in hepatic inflammation was most striking in patients in whom serum HCV RNA levels became persistently undetectable, and on the basis of previous observations, we would expect this effect to persist and to grow over time. ${ }^{27,44}$ Finally, our results emphasize that a response to an initial course of interferon does not guarantee a response after relapse, even with the use of a combination of interferon and ribavirin. Thus, every effort should be made in clinical practice and future trials to optimize the response to the first course of treatment. Currently, the best treatment option is to administer interferon for at least 12 months to patients in whom serum alanine aminotransferase concentrations or serum $\mathrm{HCV}$ RNA levels decrease soon after treatment is started. ${ }^{45}$

Supported in part by research grants from the Schering-Plough Research Institute, Kenilworth, N.J., and a Clinical Research Center grant (5MO1RR00082) from the University of Florida.

Drs. Rustgi, Gordon, and Shiffman have been members of the speakers' bureau of Schering-Plough, and Drs. Rustgi and Albrecht own stock in the corporation.

\section{APPENDIX}

In addition to the authors, the members of the International Hepatitis Interventional Therapy Group include the following: H. Bassaris, University Hospital of Patras, Patras, Greece; R. Batey, John Hunter Hospital, New Lambton Heights, Australia; K. Benner, Oregon Health Sciences University, Portland; S. Brillanti, Universita degli Studi di Bologna, Bologna, Italy; W. Carey, Cleveland Clinic Foundation, Cleveland; R. Carithers,
Jr., University of Washington, Seattle; W. Caselmann, Rheinische Friedrich Wilhelms Universität, Bonn, Germany; R. Chapman, John Radcliffe Hospital, Oxford, United Kingdom; M. Colombo, Universita degli Studi di Milano, Milan, Italy; G. Cooksley, Roval Brisbane Hospital, Brisbane, Australia; M. Carneiro de Moura, Hospital de St. Maria, Lisbon, Portugal; A. Di Bisceglie and B. Bacon, St. Louis University, St. Louis; M. Buti, Hospital Vall d'Hebron, Barcelona, Spain; G. Everson, University of Colorado, Denver; G. Farrell, University of Sydney, Sydney, Australia; A. Gauthier, Hôpital de la Conception, Marseilles, France; R. Gish, California Pacific Medical Center, San Francisco; S. Hadziannis, Hippokration Hospital, Athens, Greece; J. Heathcote, Toronto Hospital, Toronto; G. Ideo, Ospedale Niguarda Ca' Granda, Milan, Italy; I. Jacobson, New York Hospital-Cornell Medical Center, New York; R. Koff, Metro West Medical Center, Framingham, Mass.; W. Lee, University of Texas Southwestern Medical Center, Dallas; K. Lindsay, University of Southern California, Los Angeles; M. Ma, University of Alberta, Edmonton; M. Manns, Medizinische Hochschule Hannover, Hannover, Germany; G. Marenco, Ospedale S. Corona, Pietra Ligure, Italy; J. McHutchison, Scripps Clinic, La Jolla, Calif.; G. Minuk, University of Manitoba, Winnipeg; D. Mutimer, Queen Elizabeth Hospital, Birmingham, United Kingdom; N. Naoumov, University College London Medical School, London; T. Poynard, Hôpital Pitié-Salpétrière, Paris; R. Reindollar, Charlotte Clinic for Gastrointestinal Liver Diseases, Charlotte, N.C.; M. Rizzetto, Ospedale Molinette, Turin, Italy; L. Rossaro, Hershey Medical Center, Hershey, Pa.; R. Rouzier-Panis, Centre CAP, Nîmes, France; J. Sanchez-Tapias, Hospital Clinic i Provincial, Barcelona, Spain; E. Schiff, University of Miami, Miami; M. Sherman, Toronto General Hospital, Toronto; D. Shouval and Y. Ashur, Hadassah University Hospital, Jerusalem, Israel; C. Smith, Minnesota Clinical Research Center, St. Paul; N. Tassopoulas, Western Attica General Hospital, Athens, Greece; J. Vierling, Cedars-Sinai Medical Center, Los Angeles; and K. Watson, St. Vincent's Public Hospital, Fitzroy, Australia.

\section{REFERENCES}

1. Alter MJ. Epidemiology of hepatitis C. Hepatology 1997;26:Suppl l: 62S-65S.

2. Seeff LB, Buskell-Bales Z, Wright EC, et al. Long-term mortality after transfusion-associated non-A, non-B hepatitis. N Engl J Med 1992;327: 1906-11.

3. Koretz RL, Abbey H, Coleman E, Gitnick G. Non-A, non-B post transfusion hepatitis: looking back in the second decade. Ann Intern Med 1993;119:110-5

4. Mattsson L, Sonnerborg A, Weiland O. Outcome of acute symptomatic non-A, non-B hepatitis: a 13 -year follow-up study of hepatitis $\mathrm{C}$ virus markers. Liver 1993;13:274-8

5. Detre KM, Belle SH, Lombardero M. Liver transplantation for chronic viral hepatitis. Viral Hepatitis Rev 1996;2:219-28.

6. Davis GL, Balart LA, Schiff ER, et al. Treatment of chronic hepatitis C with recombinant interferon alfa: a multicenter randomized, controlled trial. N Engl J Med 1989;321:1501-6.

7. Di Bisceglie AM, Martin P, Kassianides C, et al. Recombinant interferon alfa therapy for chronic hepatitis $\mathrm{C}$ : a randomized, double-blind, placebo-controlled trial. N Engl J Med 1989:321:1506-10.

8. Tiné F, Magrin S, Craxi A, Pagliaro L. Interferon for non-A, non-B chronic hepatitis: a meta-analysis of randomised clinical trials. J Hepatol 1991;13:192-9.

9. Poynard T, Leroy V, Cohard M, et al. Meta-analysis of interferon randomized trials in the treatment of viral hepatitis C: effects of dose and duration. Hepatology 1996;24:778-89.

10. Poynard T, Bedossa $P$, Chevallier $M$, et al. A comparison of three interferon alfa-2b regimens for the long-term treatment of chronic non-A, non-B hepatitis. N Engl J Med 1995;332:1457-62. [Erratum, N Engl J Med 1996;334:1143.]

11. Lin R, Roach E, Zimmerman M, Strasser S, Farrell GC. Interferon alfa- $2 b$ for chronic hepatitis $C$ : effects of dose increment and duration of treatment on response rates: results of the first multicentre Australian trial. J Hepatol 1995;23:487-96.

12. Shiffman ML, Hoffman CM, Luketic VA, Sanyal AJ, Contos MJ, Mills AS. Improved sustained response following treatment of chronic hepatitis $\mathrm{C}$ by gradual reduction in the interferon dose. Hepatology 1996;24:21-6. 13. Carithers RL Jr, Emerson SS. Therapy of hepatitis C: meta-analysis of interferon alfa-2b trials. Hepatology 1997;26:Suppl 1:83S-88S.

14. Patterson JL, Fernandez-Larsson R. Molecular mechanisms of action of ribavirin. Rev Infect Dis 1990;12:1132-46.

15. Dusheiko G, Main J, Thomas H, et al. Ribavirin treatment for patients with chronic hepatitis C: results of a placebo-controlled study. J Hepatol 1996;25:591-8

16. Di Bisceglie AM, Shindo M, Fong T-L, et al. A pilot study of ribavirin therapy for chronic hepatitis C. Hepatology 1992;16:649-54. 
17. Bodenheimer HC Jr, Lindsay KL, Davis GL, Lewis JH, Thung SN, Seeff LB. Tolerance and efficacy of oral ribavirin treatment of chronic hep atitis C: a multicenter trial. Hepatology 1997;26:473-7.

18. Brillanti S, Garson J, Foli M, et al. A pilot study of combination therapy with ribavirin plus interferon alfa for interferon alfa-resistant chronic hepatitis C. Gastroenterology 1994;107:812-7.

19. Chemello L, Cavalletto L, Bernardinello E, Guido M, Pontisso P, Alberti A. The effect of interferon alfa and ribavirin combination therapy in naive patients with chronic hepatitis C. J Hepatol 1995;23:Suppl 2: 8-12.

20. Schvarcz R, Yun ZB, Sonnerborg A, Weiland O. Combined treatment with interferon alpha- $2 \mathrm{~b}$ and ribavirin for chronic hepatitis $\mathrm{C}$ in patients with a previous non-response or non-sustained response to interferon alone. J Med Virol 1995;46:43-7.

21. Reichard O, Norkrans G, Fryden A, Braconier JH, Sonnerborg A, Weiland O. Randomised, double-blind, placebo-controlled trial of interferon alpha- $2 \mathrm{~b}$ with and without ribavirin for chronic hepatitis $\mathrm{C}$. Lancet 1998;351:83-7.

22. Alberti A, Chemello L, Noventa F, Cavalletto L, De Salvo G. Therapy of hepatitis C: re-treatment with alpha interferon. Hepatology 1997;26: Suppl 1:137S-142S.

23. Marcellin P, Pouteau M, Boyer N, Castelnau C, Erlinger S, Benhamou JP. Retreatment with recombinant interferon-alpha in patients with chronic hepatitis C. J Infect Dis 1993;167:780-1.

24. Pocock SJ, Simon R. Sequential treatment assignment with balancing for prognostic factors in the controlled clinical trial. Biometrics 1975;31: 103-15.

25. Davis GL, Lau JYN. Factors predictive of a beneficial response to therapy of hepatitis C. Hepatology 1997;26:Suppl 1:122S-127S

26. Davis GL, Lau JYN, Urdea MS, et al. Quantitative detection of hep atitis $C$ virus RNA with a solid-phase signal amplification method: definition of optimal conditions for specimen collection and clinical application in interferon-treated patients. Hepatology 1994;19:1337-41.

27. Marcellin $P$, Boyer N, Gervais A, et al. Long-term histologic improvement and loss of detectable intrahepatic HCV RNA in patients with chronic hepatitis $\mathrm{C}$ and sustained response to interferon-alpha therapy. Ann Intern Med 1997;127:875-81.

28. Lindsay KL. Therapy of chronic hepatitis C: overview. Hepatology 1997; 26:Suppl 1:71S-77S

29. Knodell RG, Ishak KG, Black WC, et al. Formulation and application of a numerical scoring system for assessing histological activity in asymptomatic chronic active hepatitis. Hepatology 1981;1:431-5

30. Bedossa P, Poynard T. An algorithm for the grading of activity in chronic hepatitis C: the METAVIR Cooperative Study Group. Hepatology $1996 ; 24: 289-93$
31. Fleiss JL. The design and analysis of clinical experiments. New York: John Wiley, 1986.

32. Lau JYN, Davis GL, Kniffen J, et al. Significance of serum hepatitis C virus RNA levels in chronic hepatitis C. Lancet 1993;341:1501-4. [Erratum, Lancet 1993;342:504.]

33. Davis GL. Prediction of response to interferon treatment of chronic hepatitis C. J Hepatol 1994;21:1-3.

34. Martinot-Peignoux $M$, Marcellin $P$, Pouteau $M$, et al. Pretreatment se rum hepatitis $C$ virus RNA levels and hepatitis $C$ virus genotype are the main and independent prognostic factors of sustained response to interferon alfa therapy in chronic hepatitis C. Hepatology 1995;22:1050-6.

35. Dusheiko G. Side effects of alpha interferon in chronic hepatitis C. Hepatology 1997;26:Suppl 1:112S-121S.

36. Shindo M, Arai K, Sokawa $Y$, Okuno T. Hepatic hepatitis C virus RNA as a predictor of a long-term response to interferon- $\alpha$ therapy. Ann Intern Med 1995;122:586-91.

37. Picciotti A, Brizzolara R, Campo N, et al. Two year interferon retreatment may induce a sustained response in relapsing patients with chronic hepatitis C. Hepatology 1996:24:Suppl:273A. abstract.

38. Le $X$, Zhou X, Dai X. Evaluation of interferon- $\alpha-2 b$ for the treatment of relapsed hepatitis-C. Hepatology 1996;24:Suppl:536A. abstract.

39. Fuschi P, Almasio P, Di Marco V, et al. Should patients with chronic hepatitis $\mathrm{C}$ who relapse after interferon (IFN) be retreated? J Hepatol 1997;26:Suppl 1:192. abstract.

40. Keeffe EB, Hollinger FB, Consensus Interferon Study Group. Therapy of hepatitis C: consensus interferon trials. Hepatology 1997;26:Suppl 1: 101S-107S

41. Toyoda $H$, Nakano $S$, Takeda I, et al. Retreatment of chronic hepatitis C with interferon. Am J Gastroenterol 1994;89:1453-7.

42. Bonkovsky HL, Clifford BD, Smith LJ, Allan C, Banner B. High-dose interferon alfa- $2 \mathrm{~b}$ for re-treatment of nonresponders or relapsing patients with chronic hepatitis C: a controlled randomized trial. Dig Dis Sci 1996; 41:149-54.

43. Hawkins A, Davidson F, Simmonds P. Comparison of plasma virus loads among individuals infected with hepatitis $\mathrm{C}$ virus $(\mathrm{HCV})$ genotypes 1,2 , and 3 by quantiplex HCV RNA assay versions 1 and 2, Roche Monitor assay, and an in-house limiting dilution method. J Clin Microbio 1997;35:187-92.

44. Reichard $\mathrm{O}$, Glaumann $\mathrm{H}$, Fryden $\mathrm{A}$, et al. Two-year biochemical, virological, and histological follow-up in patients with chronic hepatitis $\mathrm{C}$ responding in a sustained fashion to interferon alfa- $2 \mathrm{~b}$ treatment. Hepatology 1995;21:918-22.

45. National Institutes of Health Consensus Development Conference Panel statement: management of hepatitis C. Hepatology 1997;26:Suppl $1: 2 S-10 S$ 